During pregnancy women were asked about their alcohol consumption and divided into three groups: group 1 (152 deliveries) consisted of women who drank less than once a month; group 2 (128 deliveries) of women who drank at least once a month but did not, on average, exceed $45 \mathrm{ml}$ of absolute alcohol a day; and group 3 (42 deliveries) of women who consumed on average more than $45 \mathrm{ml}$ of absolute alcohol a day. Significantly more infants born to women in group 3 were premature or small for gestational age, but there was no difference in these respects between groups 1 and 2 .

Certainly we cannot be didactic about the effect of moderate alcohol consumption on the fetus. An occasional drink seems unlikely, on present evidence, to affect the infant's birth weight; but a line cannot be drawn between amounts safe and dangerous for the fetus. Collection of data in Britain would be helpful. The French study ${ }^{9}$ indicated that the type of drink might be important: perinatal mortality and growth retardation were more apparent in the infants of women who drank beer than of those who drank wine. Meanwhile obstetricians would be wise to urge women to cut down their alcohol intake once they become pregnant.

1 Green, H G, American fournal of Obstetrics and Gynecology, 1974, 118, 713.

2 Jones, K L, and Smith, D W, Lancet, 1973, 2, 999.

3 Mulvihill, J J, and Yeager, A M, Teratology, 1976, 13, 345.

4 British Medical fournal, 1976, 2, 1404.

Stockard, C R, and Papinicolaou, G N, fournal of Experimental Zoology, 1918, 26, 119.

${ }^{6}$ Bluhm, A, Archiv für Rassen und Gesellschafts Biologie, 1930, 24, 12.

- Pilström, L, and Kiessling, K H, Acta Pharmacologica et Toxicologica, $1967,25,225$.

* Ulleland, C, et al, Pediatric Research, 1970, 4, 474.

${ }^{9}$ Kaminski, M, Rumeau-Rouquette, C, and Schwartz, D, Revue d'Epidemiologie et Medécine Sociale de Santé Publique, 1976, 24, 27.

1" Little, R E, American fournal of Public Health, 1977, 67, 1154.

11 Ouellette, E M, et al, New England fournal of Medicine, 1977, 297, 528.

\section{Hormone receptors in breast cancer}

Various sex steroid hormones are known to bind to receptors in the tumour tissue of some patients with breast cancer; the receptors act as multipliers, concentrating the growth-promoting hormones in the neoplastic tissue and increasing its ability to synthesise RNA and protein. ${ }^{1}$ Cikes $^{2}$ has suggested that these receptors for growth-promoting hormones, whose effect may parallel ectopic hormone production by tumours, may enable neoplastic cells to escape growth control. Receptors for oestrogen, ${ }^{3}$ progesterone, ${ }^{4}$ and androgen ${ }^{5}$ have been identified in human breast cancer by various assay procedures.

Assays of specific steroid receptor proteins make use of the receptors' ability to bind tightly to tritium-labelled steroids. The dextran-coated charcoal method ${ }^{6}$ relies on the ability of charcoal to absorb free steroid, the addition of dextran limiting absorption of steroid-receptor complexes. This method is relatively easy, fast, and sensitive and does not require expensive equipment, but cannot identify the molecular form of the receptor. The sucrose gradient technique ${ }^{7}$ is slow and expensive, but it does distinguish the molecular forms. Other assay methods include agar-gel electrophoresis, ${ }^{*}$ protamine sulphate precipitation, ${ }^{9}$ hydroxyapatite adsorption, ${ }^{10}$ and Sephadex gel filtration. ${ }^{11}$ At present no one assay is ideal, but in terms of simplicity and cost the dextran-coated charcoal method is probably the best.

The proportion of breast cancers that contain oestrogen receptors (ER) varies in reported series from 35 to $85 \%$. The proportion has risen over the years, possibly reflecting technical i mprovements in assays. ${ }^{1}$ Tumour tissue from metastatic sites examined at different stages of the disease has shown little variation from the primary tumour. ${ }^{12}$ The concentration of receptors in ER-positive patients varies over a wide range, ${ }^{13}$ however; and Leclercq and Heuson ${ }^{1}$ have suggested that most, if not all, breast tumours contain receptors, though in some cases their concentration is too low to be detected with the current assays. Many investigators now use an arbitrary minimum concentration of receptors to define ER-positive tumours. The mean concentration of receptors is lower in premenopausal women. ${ }^{14}$

Larger series, including an international review, ${ }^{15} 16$ have shown that $60^{\circ}{ }^{\circ}$ of patients with ER-positive breast tumours respond to treatment by hormonal manipulation. In contrast, only $8-16^{\circ}$ " of ER-negative patients respond to similar treatment. ${ }^{1}$ Correlation of ER measurements with clinical variables improves accuracy in predicting this response. ${ }^{1}$

Progesterone receptors (PgR) have been reported in 30-60\% of breast cancers ${ }^{17}$; they occur only in patients who are ERpositive. ${ }^{1}$ Progesterone receptors may therefore indicate an intact ER system, and a finding of both ER and PgR positivity might be expected to correlate closely with hormonal responsiveness. Early data $1 \times 19$ seemed to substantiate this hypothesis, but Leclercq's small study ${ }^{1}$ did not support it and further investigation is needed. Few data are available on the predictive values of androgen receptors (AR), which have been detected in $20-50^{\circ}$ o of breast cancers, ${ }^{1}$ though hormonal responsiveness has been recorded in small numbers of AR-positive patients. ${ }^{5} 20$

Though hormone receptors (and especially ER) have improved our ability to predict hormonal responsiveness in breast cancer, there is still a large unexplained false-positive rate. Some tumours may be composed of a mixed population of receptorpositive and receptor-negative cells; continued growth of negative cells would then lead to hormonal insensitivity. Alternatively, loss of the cells' ability to transfer the cytoplasmic oestrogen-receptor complex to the nucleus may account for false-positives; the new generation of assays for nuclear receptors will therefore be important.

There is no a priori reason why cells with receptors for certain hormones should respond to treatment with other hormones. But clearly in human breast cancer there may be many interactions between different hormones, including prolactin; and levodopa, a prolactin antagonist, has been used as a predictor of hormonal responsiveness. In two small studies ${ }^{2122}$ levodopa relieved bone pain in some patients, a positive result predicting response to subsequent endocrine ablation and correlating well with the presence of oestrogen receptors. Further trials are needed in suitable patients to see whether levodopa provides a useful test for patients in whom receptor assays are not done.

The place of hormone receptor assays in the routine management of metastatic breast cancer remains unsettled. Detecting oestrogen receptors can predict hormone responsiveness in $60^{\circ}{ }_{0}$ of ER-positive patients and prevent unnecessary surgical hormonal manipulations in receptor-negative patients. Against this we must weigh the cost and investment in facilities required to make assays generally available. Furthermore, if the primary use of non-surgical hormonal manoeuvres and more successful alternative systemic treatments become general in advanced breast cancer ablative surgical procedures would diminish in importance.

Despite this, assessment of ER state at the time of initial surgery would simplify the present-day management of many patients-the cost being somewhat offset by the avoidance of unnecessary surgery. As a future treatment, the use of cytotoxic agents linked to sex-steroid hormones remains a thoughtprovoking though unfulfilled possibility. ${ }^{1}$ Studies of hormonal receptors are now being extended to tumours other than breast cancer.

${ }^{1}$ Leclercq, G, and Heuson, J C, European fournal of Cancer, 1977, 13, 1205.

${ }^{2}$ Cikes, M, European Fournal of Cancer, 1978, 14, 211

${ }^{3}$ Korenman, S G, and Dukes, B A, fournal of Clinical Endocrinology, 1970, 30, 639.

${ }^{4}$ Horwitz, K B, et al, Science, 1975, 189, 726.

${ }^{5}$ Maass, H, fournal of Steroid Biochemistry, 1975, 6, 743.

${ }^{6}$ EORTC Breast Cancer Group, European fournal of Cancer, 1973, 9, 379

'Jensen, E V, et al, in Estrogen Receptors in Human Breast Cancer, eds W I McGuire, P P Carbone, and E P Vollmer, p 37. New York, Raven Press, 1975.

${ }^{8}$ Wagner, R K, Hoppe-Seyler's Zeitschrift für Physiologische Chemie, 1972, $353,1235$. 
${ }^{9}$ Chamness, G C, Huff, K, and McGuire, W L, Steroids, 1975, 25, 627.

${ }^{10}$ Erdos, T, Brest-Belpomme, M, and Bessada, R, Analytical Biochemistry, $1970,37,244$

${ }^{11}$ Singhakowinta, A, et al, in Estrogen Receptors in Human Breast Cancer, eds W L McGuire, P P Carbone, and E P Vollmer, p 131. New York, Raven Press, 1975.

12 King, R J B, Cancer Treatment Reviews, 1975, 2, 273.

13 Leclercq, G, et al, British Medical fournal, 1975, 1, 185.

${ }^{14}$ Legha, S S, Davis, H L, and Muggia, F M, Annals of Internal Medicine, $1978,88,69$.

${ }^{15}$ McGuire, W L, et al, in Estrogen Receptors in Human Breast Cancer, eds W L McGuire, P P Carbone, and E P Vollmer, p 1. New York, Raven Press, 1975.

${ }_{16}$ Jensen, E V, Cancer Research, 1975, 35, 3362.

17 Raynaud, J P, et al, in Progesterone Receptors in Normal and Neop!astic Tissue, eds W L McGuire, J P Raynaud, and E E Baulieu, p 171. New York, Raven Press, 1977.

${ }^{18}$ Bloom, V, Tobin, E, and Degenshein, G A, in Progesterone Receptors in Normal and Neoplastic Tissue, eds W L McGuire, J P Raynaud, and E E Baulieu, p 125. New York, Raven Press, 1977.

${ }^{19}$ Horwitz, K B, and McGuire, W L, in Progesterone Receptors in Normal and Neoplastic Tissue, eds W L McGuire, J P Raynaud, and E E Baulieu, p 103. New York, Raven Press, 1977.

${ }^{20}$ Persijn, J P, Korsten, C B, and Engelsman, E, British Medical fournal, $1975,4,503$.

${ }^{21}$ Minton, J P, and Bell, J L, Proceedings of the American Association for Cancer Research, 1975, 16, 230.

${ }^{22}$ Sasaki, G H, Leung, B S, and Fletcher, W S, Annals of Surgery, 1976, $183,392$.

\section{Two decisions for Cardiff}

Is the Review Body a valuable protection for the profession's interests? Or is it merely the velvet glove on the Treasury's iron-fisted parsimony? Since 1962, when the Review Body was set up, the profession's views on it have varied with the value of its awards. But on balance the system has helped rather than hindered doctors in their financial dealings with a state monopoly employer. This year there is once again a sharp division of opinion between junior doctors and the rest of the profession on the Review Body's future. The juniors' representatives want to withdraw from the system and negotiate direct with the Government on pay. 1 The consultants, general practitioners, and community physicians value the Review Body and want to keep it. The Representative Body next week will be listening to the arguments and making up its mind.

Let us hope that the ARM at Cardiff hears all the arguments. At the BMA's Hospital Junior Staff Conference the case in favour of the Review Body was rather faintly heard, though Dr D T Roberts, the juniors' chief negotiator, sounded a cautionary note. No one seemed clear about what form of direct negotiations would supplant the present system. Would it be direct negotiation between the BMA's Hospital Junior Staff Committee and the DHSS ? Might the Government press for a negotiating panel of various junior organisations? Or perhaps the juniors would be invited to activate the moribund hospital doctors' committee in the Whitley machinery. Furthermore, what would be the effect of the juniors' unilateral withdrawal on other branches of the profession who preferred the status quo? Nurses have directly bargained for years, but have doctors forgotten that the best award to nurses in recent years was the "one off" independent review by Lord Halsbury ?2 Why did a leading public sector trade unionist recently fly the kite of an independent review board for all public sector workers? Was he disillusioned with direct bargaining ? Have union bargainers in the public sector done that much better under pay policy than doctors?

Most of the doctors' recent pay troubles have been the result of successive pay policies. In this respect, what the Review Body should have done before 1978-though this year it has rectified the omission handsomely - was to make public its view of doctors' worth and left the Government to cut the award to fit the pay policy. And one final question for the supporters of direct bargaining: will doctors be prepared again to take industrial action to support a pay claim ? The juniors' conference may have been farsighted in judging that the Review Body has served its purpose and that changing times require new methods. But before the Representative Body votes on the future of the independent Review system it should seek the answers to these questions. It might also ponder on the following statement from the Top Review Body's latest report, published last week. "We have to record our unanimous view that it will be difficult for any system of independent review to operate effectively in the 'top salaries' field. In this context, we observe that, for more than thirty years, no real alternative has been found. Independent judgment from some form of independent body, informed both by evidence and by relevant experience among its members, appears to be the best safeguard both of proper rewards for the four groups within our terms of reference and of the public interest." 3

The issue of the Review Body affects the whole profession, so the BMA has a crucial co-ordinating task in ensuring a democratic decision that is in the interests of all NHS doctors. The reconstituted Representative Body has already shown its capabilities on this score. ${ }^{4}$ This year at Cardiff the BMA's policy-making body will make several far-reaching decisions affecting the whole profession-on confidentiality, clinical judgment and the Ombudsman, and doctors' authority in the NHS. But one item will be particularly important to BMA members: how to reshape the Association's peripheral structure. The debate will centre on the Clark working party's report on the functions and priorities of the Association. ${ }^{5}$

The report makes some valuable observations, not least in warning of the dangers of burgeoning bureaucracy at BMA House as a result of a proliferating committee structure and a "wasteful and inefficient" committee procedure. Indeed, for too many "average members" the BMA is a distant minibureaucracy in London. If the Association is to flourish active membership should be seen to have advantages denied to the non-member doctor in terms of expert professional and medicopolitical advice and participation in policy making. To do this the association must refurbish its local structure to fit the age of unionism-while retaining its professional activities and influence-and provide every member with a positive accessible BMA identity. Few doctors will dispute the principle behind the Clark working party's conclusions-namely, the appointment of more trained staff to work for BMA members at local level. Arguments will flourish, however, about how best to do this, including how to co-ordinate the needs of salaried doctors with those of GPs-independent contractors who in law are excluded from some aspects of union recognition.

Reports so far on the recently appointed provincial medical secretaries suggest that the scheme is welcomed. Any expansion of their role, with support by an even more comprehensive local network of "contact persons" and full-time "trade union" staff would mean the Association having to find substantial funds. There are three possibilities: the BMA could provide some money to introduce changes everywhere gradually; it could take one "pilot" region and provide the money necessary to set up a whole new peripheral structure; or it could take a daring gamble, use some of its substantial capital assets, and invest heavily in rejuvenating the BMA locally. If the Representative Body chose the last option it might prove to be one of the best investments the Association has ever made.

${ }^{1}$ British Medical fournal, 1978, 2, 66.

2 DHSS, Report of the Committee of Inquiry into the pay and conditions of service of nurses and midwives. London, HMSO, 1974.

${ }^{3}$ Review Body on Top Salaries, Report No 10: Second Report on Top Salaries, Cmnd 7253. London, HMSO, 1978.

${ }^{4}$ British Medical fournal, 1977, 2, 349.

5 British Medical fournal, 1978, 1, 916. 